\title{
The Effects of Materialism and Hedonic Shopping Value on the Impulse Buying Behavior: A Study on University Students in Turkey
}

\author{
DOI: 10.26466/opus.778848
}

\author{
* \\ Bora Açan $^{*}$ - Şeniz Özhan ${ }^{* *}$ - Duygu Talih Akkaya ** \\ * Asst.Prof.Dr., Yalova University, Yalova Vocational School, Yalova/Turkey \\ E-Mail: bora.acan@yalova.edu.tr \\ ORCID: 0000-0001-6380-897X \\ **Asst.Prof.Dr., Tekirdağ Namık Kemal University, Çorlu Vocational School, Tekirdağ/Turkey \\ E-Mail serdem@nku.edu.tr \\ ORCID: 0000-0003-3898-8192 \\ ***Asst.Prof.Dr., Yalova University, Yalova Vocational School, Yalova/Turkey \\ E-Mail: duygu.talih@yalova.edu.tr \\ ORCID: $\underline{0000-0002-7514-8347}$
}

\begin{abstract}
The purpose of this research is to determine the effects of materialism and hedonic shopping value on impulse buying behavior and the effect of materialism on hedonic shopping value. The study sample was comprised of students selected via convenience sampling method at one state university in the Marmara Region of Turkey. The analysis of the data acquired by face-to-face questionnaire method from a total of 464 university students was performed by factor analysis. Structural equation modeling was used to assess the effects of materialism and hedonic shopping value on impulse buying behavior and the effect of materialism on hedonic shopping value. The findings showed that the success dimension of materialism has a positive effect on all dimensions of hedonic shopping value and that the success and centrality dimensions of materialism have a positive effect on impulse buying behavior. Also, it was observed that the happiness dimension of materialism has a negative effect on impulse buying behavior and all dimensions of hedonic shopping value. Furthermore, it was seen that the social interaction and praise from others dimensions of hedonic shopping value have a negative effect on impulse buying behavior. These findings can help theorist and marketers better understand young people's impulse buying behaviors.
\end{abstract}

Keywords: Impulse buying behavior, materialism, hedonic shopping value, university students, Turkey. 


\section{Materyalizm ve Hedonik Alışveriş Değerinin Anlık Satın Alma Davranışı Üzerine Etkileri: Türkiye'deki Üniversite Öğrencileri Üzerine Bir Araştırma}

Öz

Bu araştırmanın amacı, materyalizm ile hedonik alışveriş değerinin anlık satın alma davranışı üzerindeki etkilerini ve materyalizmin hedonik alışveriş değeri üzerindeki etkisini belirlemektir. Çalışmanın örneklemi, Türkiye'nin Marmara Bölgesi'ndeki bir devlet üniversitesinde kolayda örnekleme yöntemi ile seçilen öğrencilerden oluşmuştur. Toplam 464 üniversite öğrencisinden yüz yüze anket yöntemi ile edinilen verilerin analizi faktör analizi ile yapılmıştır. Materyalizmin ve hedonik alışveriş değerinin anlık satın alma davranışı üzerindeki etkilerini ve materyalizmin hedonik alışveriş değeri üzerindeki etkisini değerlendirmek için yapısal eşitlik modellemesi kullanılmıştır. Bulgular, materyalizmin başarı boyutunun hedonik alı̧veriş değerinin tüm boyutlar üzerinde olumlu bir etkisinin olduğunu ve materyalizmin başarı ve merkeziyetçilik boyutlarının anlık satın alma davranışı üzerinde olumlu bir etkisinin olduğunu göstermiştir. Ayrıca, materyalizmin mutluluk boyutunun, anlı satın alma davranışı ve hedonik alışveriş değerinin tüm boyutları üzerinde negatifbir etkisinin olduğu görülmüştür. Ayrıca, hedonik alışveriş değerinin sosyal etkileşim ve başkalarından övgü boyutlarının anlık satın alma davranışı üzerinde negatif bir etkisinin olduğu görülmüştür. Bu bulgular, teorisyenler ve pazarlamacların, gençlerin anlık satın alma davranışların daha iyi anlamasına yardımcı olabilir.

Anahtar Kelimeler: $\quad$ Anlık satın alma davranışı, materyalizm, hedonik alışveriş değeri, üniversite öğrencileri, Türkiye. 


\section{Introduction}

It can be observed when studies in literature are examined that purchases made by way of impulse buying hold a significant share (Cobb and Hoyer, 1986; Kacen, 2003; Rook and Fisher, 1995; Rook and Hoch, 1985). According to a study carried out on two thousand people in determined the United States of America, an average American consumer spends about 5400 (fivethousandfourhundred) American Dollars on impulse buying annually (O'Brien, 2018). As of early $21^{\text {st }}$ century, impulse buying has reached a sales volume exceeding 4 billion dollars annually (Kacen and Lee, 2002). It has been determined that about $60 \%$ of all purchases in certain retail market groups are comprised of unplanned purchases based on a sudden impulse (Point of Purchase Advertising International [Popai], 2014).

The relationships between impulse buying behavior (IBB) and various demographic and personal factors such as gender (Aytekin and Ay, 2015; Coley and Burgess, 2003; Dittmar, Beattie and Friese, 1995; Tifferet and Herstein, 2012; Wu, I-L., Chiu, M-L. and Chen, K-W., 2020), age (Bellenger, Robertson and Hirschman, 1978; Ghani and Jan, 2011), credit card (Badgaiyan and Verma, 2015; Thomas, Desai and Seenivasan, 2011) and having money (Badgaiyan and Verma, 2015) and changes in income (Rook and Hoch, 1985) have been examined in many different studies.

It has been put forth in various former studies that IBB is positively related with materialism (Sen, Nayak, 2019; Troisi, Christopher and Marek, 2006) and hedonism (Çağlıyan, Gültekin and Gelmez, 2018; Herabadi, Verplanken and Knippenberg, 2009; Yu and Bastin, 2010). Troisi et al. (2006) determined that highly materialistic individuals have a greater tendency for impulse buying. Herabadi et al. (2009) observed that consumers live an enjoyable experience via highly emotional stimulations during impulse buying, that there are hedonic elements involved in impulse buying indicating a strong relationship between the two. However, to the best of authors' knowledge, a study by Lins et al. (2015) have been found in the literature which directly examines the effects of both materialism and hedonic shopping value (HSV) on IBB as well as the effect of materialism on HSV. Lins et al. (2015) determined that impulse buying is positively correlated with materialism and hedonism; in addition they concluded that hedonism partly mediated the effect of materialism on 
impulse buying. Also, it has been determined that the impulse buying opportunities of consumers has increased with increasing shopping channels and e-commerce; it has been indicated that non-western cultures do not have sufficient knowledge on impulse buying (Kacen and Lee, 2002). Similarly, Yu and Bastin (2010) stated that the changes that take place in non-western countries due to economic advancements and transformations leading to changes in the concepts of consumption have resulted in creating an environment suitable for impulse buying but they also indicated that the knowledge on impulse buying is low outside of the western societies. Hence, it is considered that the present study on university students in Turkey will make significant contributions to literature. Having knowledge on the relationship between materialism and HSV and the level at which they are motivations for impulse buying will provide us up to date knowledge on impulse buying tendencies in Turkey in addition to providing significant findings to the related individuals and businesses for developing and implementing suitable marketing strategies.

\section{Conceptual Background and Hypotheses Development}

\section{Materialism}

Materialism is a value that guides consumer's preferences and behaviors in various cases within consumption areas (Richins and Dawson, 1992). Materialism is the importance and value attributed to property (Belk, 1984). Materialism is an orientation that sees money and goods with monetary value as important in the path of social development and individual happiness (Ward and Wackman, 1971). One can see that materialism was stated differently by various researchers. Since having worldly possessions is at center the life of one who has adopted materialism at the highest level, it is accepted to cause the greatest satisfaction or dissatisfaction to an individual (Belk, 1984).

Richins and Dawson (1992) indicated three subjects that emerge in materialism and explained them: The first is "acquisition centrality" (p. 304) used when the desire for physical assets, having property and acquiring them is transformed into a style of life meaning that the individual consumes for the sake of consuming. The second is "acquisition as the pursuit of happiness" (p.304) which defines attaining happiness not by way of personal relations, experiences or successes but by way of acquiring physical assets since materialists 
consider it obligatory to own physical objects for satisfaction in life. Whereas the last one is "possession-defined success" (p. 304) used for the idea that success is defined by the amount and value of physical assets owned since the value of physical assets is determined based on their cost rather than the level at which they satisfy the individual because they are proofs of being a participant of the desired life not only by way of status but also by reflecting the desired self-image.

Seo and Huh (2004) carried out a study on 645 university students for determining the effect of materialism on utilitarian and hedonic shopping values as a result of which the effect of materialism on HSV was shown. Troisi et al. (2006) indicated that highly materialistic individuals seek sensation. Burroughs and Rindfleisch (2002) concluded that materialism is associated with hedonism indicating that materialist individuals seek hedonistic pleasure. Richins (1987) determined that material satisfaction or in other words the life standard satisfaction is positively related with general satisfaction for those with materialistic tendencies. Therefore, it can be said that meeting the needs by experiencing products and their functions is part of life standard satisfaction. Thus, it can be stated that the life standard due to acquired products is related with comfort, leisureliness, joy and pleasure. Hence, the following hypotheses were put forth taking into consideration that adoption of materialism by consumers has a statistically significant effect on HSV:

- H1: Success has a significant effect on the fun dimension of HSV.

- H2: Success has a significant effect on the praise from others dimension of HSV.

- H3: Success has a significant effect on the escapism dimension of HSV.

- H4: Success has a significant effect on the social interaction dimension of HSV.

- H5: Centrality has a significant effect on the fun dimension of HSV.

- H6: Centrality has a significant effect on the praise from others dimension of HSV.

- H7: Centrality has a significant effect on the escapism dimension of HSV.

- H8: Centrality has a significant effect on the social interaction dimension of HSV.

- H9: Happiness has a significant effect on the fun dimension of HSV.

- H10: Happiness has a significant effect on the praise from others dimension of HSV. 
- H11: Happiness has a significant effect on the escapism dimension of HSV.

- H12: Happiness has a significant effect on the social interaction dimension of HSV.

\section{Hedonic Shopping Value (HSV)}

Hedonism is a doctrine that accepts that everything which gives pleasure is beneficial and attractive while pleasure is the sole purpose of life (Akalın et al., 2011). Rudawska, Petljak, and Stulec (2015) indicated that the hedonic value can be considered as emotional benefits arising from the shopping experience stating that it mirrors the joy and emotional value of shopping. Shopping value is not limited only with acquiring a product but is actualized by way of "complete shopping experience" (Babin, Darden and Griffin, 1994, p. 645).

Tauber (1972) carried out a study on the reasons for buying in which it was indicated that consumers do not decide to go shopping only when they need a certain product but that they are also motivated for shopping when they want to meet people with similar interests, when they want to spend their free time, be with their peers, exercise and need attention. Hence, all consumer behaviors are not based solely on meeting functional, economic or physical needs and consumer value can be utilitarian as well as hedonistic (Babin et al., 1994). Utilitarian shopping value is described as buying behaviors that are directed towards a certain goal, that are rational and task oriented, and whereas HSV is more emotional, experiential and personal in comparison with the utilitarian shopping value and indicates the relationship between reference groups and consumers while also showing the potential entertainment value of shopping (Yu and Bastin, 2010). Therefore, hedonic buying, hedonic values are important elements in the life of consumers.

$\mathrm{Yu}$ and Bastin (2010) carried out a study in which they examined the impulse buying behaviors of consumers within the framework of HSV aiming to define the dimensions of HSV. Novelty from among these dimensions, also known as idea shopping in other studies, indicates seeing new products and keeping up with new trends (Arnold and Reynolds, 2003). Fun is defined as the meeting of the needs of consumers for dreaming as well as aesthetics, pleasure or emotional relaxation (Ducoffe, 1996). Many individuals enjoy and 
are motivated by receiving praise from people around them on what they do, wear, eat and/or the roles they take on during their daily lives. Yu and Bastin (2010) indicated that consumers value praise from others and compliments and that their impulse buying probability is significantly increased in a positive manner. Escapism is a means for the individual to escape from an unhappy state or their concerns. In addition, excessive emotional stimulation and an active imagination intensify the anxieties experienced. Therefore, such individuals may feel a greater need to take part in activities that enable them to forget their problems and escape from the undesired realities of daily life (Hirschman, 1983). Social interaction dimension expresses the joy of shopping with family and friends as well as the joy of socializing and establishing bonds with others while shopping and reflects the tendency for closeness in interpersonal relations during shopping (Arnold and Reynolds, 2003).

Babin et al. (1994) conducted a study with an approach accepting that all consumer behaviors are not geared towards meeting certain functional, physical or economic needs as a result of which a positive relationship was determined between unplanned purchases including impulse buying and HSV. Rook (1987) carried out a study in which it was put forth that intensive emotional states accompany the impulse buying urge, that the emotions which accompany impulse buying include hedonic elements for about half of the participants and that impulse buying is accompanied by emotions that make them feel bad for some of the consumers. Miao (2011) concluded that there is a relationship between IBB and HSV. Mamuaya and Tumiwa (2017) determined that the hedonic shopping motivation has a major effect on impulse buying. Aytekin and Ay (2015) carried out a study in which a positive and weak but statistically significant relationship was determined between hedonic consumption and IBB. Lins et al. (2015) determined that hedonic shopping motivation is positively correlated with impulse buying. $\mathrm{Yu}$ and Bastin (2010) carried out a study investigating the relationship between the HSV of Chinese consumers and their tendencies for impulse buying as a result of which significant results were acquired indicating that there are strong relations between impulse buying and hedonic responses and especially fun, novelty and praise from others. However, they also concluded that impulse buying intention is positively related with escapism and negatively related with social interaction and that these two relations are not statistically significant. Based on these results, it can be indicated that the HSV is an important 
motivation for IBB. The following hypotheses were put forth based on these findings:

- H13: Fun has a significant effect on IBB.

- H14: Praise from others has a significant effect on IBB.

- H15: Escapism has a significant effect on IBB.

- H16: Social interaction has a significant effect on IBB.

\section{Impulse Buying Behavior (IBB)}

Rook (1987) indicated that the purchase impulse is hedonically complex which may result in an emotional conflict in the consumer, and IBB is a sudden, effective and stubborn desire for consumers to buy anything immediately.

Stern (1962) stated that impulse buying is used synonymously with unplanned buying used for purchases of the consumer that were not planned beforehand. In later years, Rook (1987) put forth that impulse buying is a more specific concept with a narrower scope in comparison with unplanned buying indicating that impulse buying is a unique psychological behavior that is different from planned buying behaviors. According to Beatty and Ferrell (1998), the impulse buying involves experiencing the urge to purchase, albeit unplanned. Impulse buying has been described as purchase that involves an emotional answer to a stimulating object without previous planning or thought ("Impulse Purchase", n.d.). Based on these explanations, it can be stated that every impulse buying is an unplanned purchase. However, every unplanned purchase cannot be defined as impulse buying.

Visual contact with a product or promotion stimulant may result in impulse buying response in the consumers; however impulse buying stimulus can also emerge without any visual contact. It has been observed that some individuals suddenly go out with an impulse to buy something without any contact with an external stimulant (Rook, 1987). Stern (1962) classified IBB as suggestion, reminder, pure and planned impulse buying that is, impulse purchase that takes place when shopping for previously planned products. Rook and Hoch (1985) explained impulse buying with a psychological model comprised of five factors, which are disregarding the consequences of impulse purchase; a decrease in cognitive assessment; the beginning of psychological 
conflict; a state of psychological disequilibrium and desire to act suddenly and spontaneously, thereby putting forth the characteristics that reveal IBB.

There are different factors indicated in the literature that affect the impulse buying experience. Researchers such as Stern (1962) and Kollat and Willett (1969) have put forth that IBB is triggered when the individual is subject to a stimulant such as advertisement, store arrangement, sales personnel and promotion activities. Whereas some researchers (Amos, Holmes and Keneson, 2014; Badgaiyan and Verma, 2014) have focused on examining the consumer behavior during the purchasing decision making process in order to define the external factors such as situational, store and product characteristics and internal factors such as personal characteristics that trigger impulse buying. The sensory and environmental factors in a store environment controlled by the marketers such as visual factors, advertisements, promotions, scent, music, product price are defined as external cues that trigger IBB, whereas the positive and negative moods of consumers and their mental states are defined as internal cues that trigger IBB (Youn and Faber, 2000). Lins et al. (2013) indicated the three elements that characterize the tendency for impulse buying as; materialism, hedonic motives and need for cognition.

Troisi et al. (2006) determined that highly materialistic individuals have higher impulse buying tendencies. Lins et al. (2015) determined that materialism is positively associated with impulse buying. It was put forth in various studies that materialism is an important and significant predictor of the time spent on shopping and that those with high materialistic tendencies shop more frequently and spend more time (Fitzmaurice and Comegys, 2006) and money on shopping (Fitzmaurice and Comegys, 2006; Garðarsdóttir and Dittmar, 2012; Watson, 2003). When it is taken into consideration that these results, the following hypotheses were developed:

- H17: Success has a significant effect on IBB.

- H18: Centrality has a significant effect on IBB.

- H19: Happiness has a significant effect on IBB.

\section{Method}

Survey methodology was used in the present study. The following sections explain the research model, data source and sample, measurement instrument and data analysis. 


\section{Research Model}

Figure 1, shows the research model put forth based on the relations determined by way of the hypotheses on materialism, HSV and IBB. In the context of the model, the effects of each dimension of materialism and each dimension of HSV are examined separately.

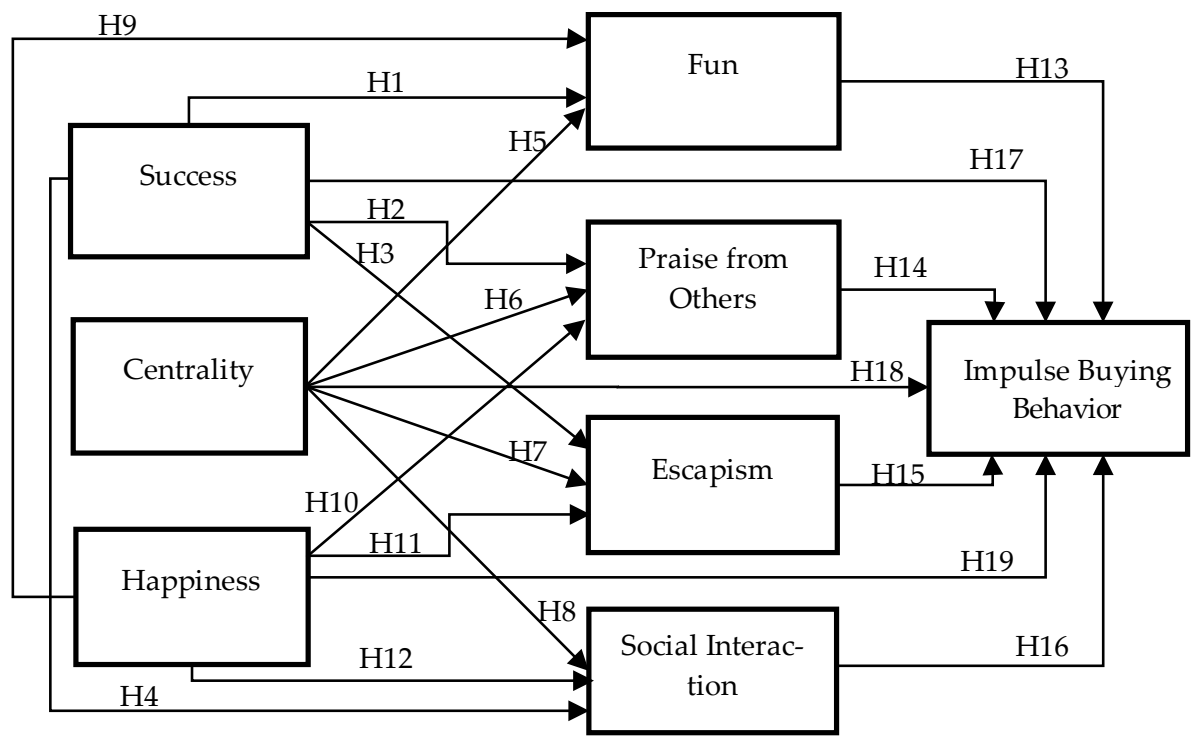

Figure 1. Research Model

\section{Data Source and Sample}

Data acquired via face-to-face questionnaire method applied on students at one state university in the Marmara Region, which is the most developed region of Turkey, were used in the present study. The Marmara Region has the largest youth population with almost three million seven hundred thousand individuals between the ages of 15-24 (TUIK, 2019). State universities in the Marmara Region are preferred by many students with different socio-economic levels from all regions in Turkey. University students correspond to the young population and young people are targeted more and more by marketers since they make up the consumers of the future, they use new technologies more and since marketing communication mostly takes place by way of internet technologies in our day which makes them be more sensitive to 
specific buying behaviors such as impulse buying. Even though there are various studies in literature on IBB, the number of studies on university students is relatively low and thus the present study has been carried out on university students in Turkey.

Written approvals were acquired from the Social Sciences Research Ethics Committee of Yalova University (report date: April 02, 2019) for this study.

Verbal informed consent was taken from the students prior to the survey application and the students were informed that the survey is on impulse buying, materialism and HSV. Moreover, they were also informed that they may refuse to respond to the survey at any time.

There are a total of 12.640 associate degree and undergraduate degree students on the university in question (Yalova University, 2019). According to Sekeran (1992), the sufficient sample group size is 375 if the main mass is comprised of 15.000 units. Sample units were selected via convenience sampling method from among non-random sampling methods. The questionnaire was applied on 521 students and 464 questionnaires were included in the analysis after excluding incomplete or incorrectly filled questionnaires. The demographics of the students are reported in Table 1.

\section{Table 1. Demographics of the Students}

\begin{tabular}{|c|c|c|c|c|c|}
\hline Gender & $\mathrm{f}$ & $\%$ & Age & $\mathrm{F}$ & $\%$ \\
\hline Female & 273 & 58,8 & $18-20$ & 285 & 61,4 \\
\hline Male & 191 & 41,2 & $21-23$ & 155 & 33,4 \\
\hline Monthly Household Income & $\mathrm{f}$ & $\%$ & $24-26$ & 16 & 3,5 \\
\hline 2000 TRY $<$ & 106 & 22,8 & $27+$ & 8 & 1,7 \\
\hline 2001-4000 TRY & 227 & 48,9 & Educational Status & $\mathrm{f}$ & $\%$ \\
\hline 4001-6000 TRY & 82 & 17,7 & Associate degree student & 172 & 37,1 \\
\hline 6001-8000 TRY & 22 & 4,7 & Undergraduate degree student & 292 & 62,9 \\
\hline 8001-10000 TRY & 17 & 3,7 & & & \\
\hline $10001 \mathrm{TRY}>$ & 10 & 2,2 & & & \\
\hline Total & & & & 464 & 100 \\
\hline
\end{tabular}

When Table 1 is examined, it is seen that majority of the students who took part in the research were female $(58,8 \%)$, between the $18-20$ age interval $(61,4$ $\%)$, were undergraduate degree students $(62,9 \%)$ and that about half of them (48,9\%) had a monthly family income of 2001-4000 TRY.

\section{Measurement Instrument}

Scales the reliability and validity of which have been proven by way of scientific studies have been used in the questionnaire of the present study. The 
questionnaire consisted of four parts. In the first part, materialism was measured via the 18 item materialism scale developed by Richins and Dawson (1992); in the second part, the dependent variable of the research, IBB was measured via the 9 item buying impulsiveness scale developed by Rook and Fisher (1995) and in the third part, HSV was measured via the 15 item HSV scale developed by $\mathrm{Yu}$ and Bastin (2010). The scales were first translated into Turkish after which the Turkish text was translated once again into English by different translators based on the back-translation method thereby correcting the semantic shifts. Linguistic equivalence study was then carried out to ensure consistency between the original scale and its Turkish version thus giving the scale its final form. Each of the expressions in the scales were prepared as 5-point Likert type ranging between I do not agree at all=1 and I completely agree $=5$. Demographic items such as age, gender and income were included in the questionnaire in addition to these scales.

\section{Data Analysis}

The data obtained were coded and uploaded to the computer. The data were analyzed via SPSS 17 and SPSS Amos 24 software. Frequency distributions, factor analysis and Structural Equation Modeling (SEM) were used for data analysis.

\section{Findings}

Structural validity was tested with factor analysis. Therefore, explanatory factor analysis was used to the scales in the study. As a result of the first factor analysis applied to each of the scales; those with an unstable structure, or in other words those with similar factor loads under different factors and variables with factor loads of less than 0,5 were excluded after which the analyses were repeated. As can be seen in Table 2, it can be observed that the KMO value is above the lowest desired value of 0,50 with 0,894 in the impulse buying scale; 0,889 in the HSV scale and 0,742 in the materialism scale (Hair, Black, Babin and Anderson, 2014). The Bartlett test values of all three scales were statistically significant $(p=0,000)$. As can be seen, the data sets of all three scales are suited for factor analysis. 
The Effects of Materialism and Hedonic Shopping Value on the Impulse Buying Behavior: A Study on University Students in Turkey

Table 2. KMO Measure of Sampling Adequacy and Bartlett's Test

\begin{tabular}{lllll}
\hline & & $\begin{array}{l}\text { Impulse } \\
\text { Buying } \\
\text { (IBB) Scale }\end{array}$ & $\begin{array}{l}\text { Hedonic } \\
\text { Shopping Value } \\
\text { (HSV) Scale }\end{array}$ & $\begin{array}{l}\text { Materialism } \\
\text { Scale }\end{array}$ \\
\hline $\begin{array}{l}\text { Kaiser-Meyer-Olkin Measure } \\
\text { of Sampling Adequacy }\end{array}$ &, 894 &, 889 &, 742 \\
$\begin{array}{l}\text { Bartlett's Test of Sphericity } \\
\text { Approx. Chi-Square }\end{array}$ & $\begin{array}{l}1600,224 \\
\text { Degrees of Freedom (df) }\end{array}$ & 36 & 2568,498 & 682,486 \\
& Level of Significance (Sig) &, 000 &, 000 & 36 \\
\hline
\end{tabular}

Principal Component Analysis was used as the method for factor analysis and Direct Oblimin (Delta: 0) was preferred as the rotation method. The acquired factors, their eigen values, the factor loads for the variables of these factors, the variance explained by each factor and the total variance along with the reliability values for these factors can be seen in Table 3 .

Table 3. Result of the Explanatory Factor Analysis

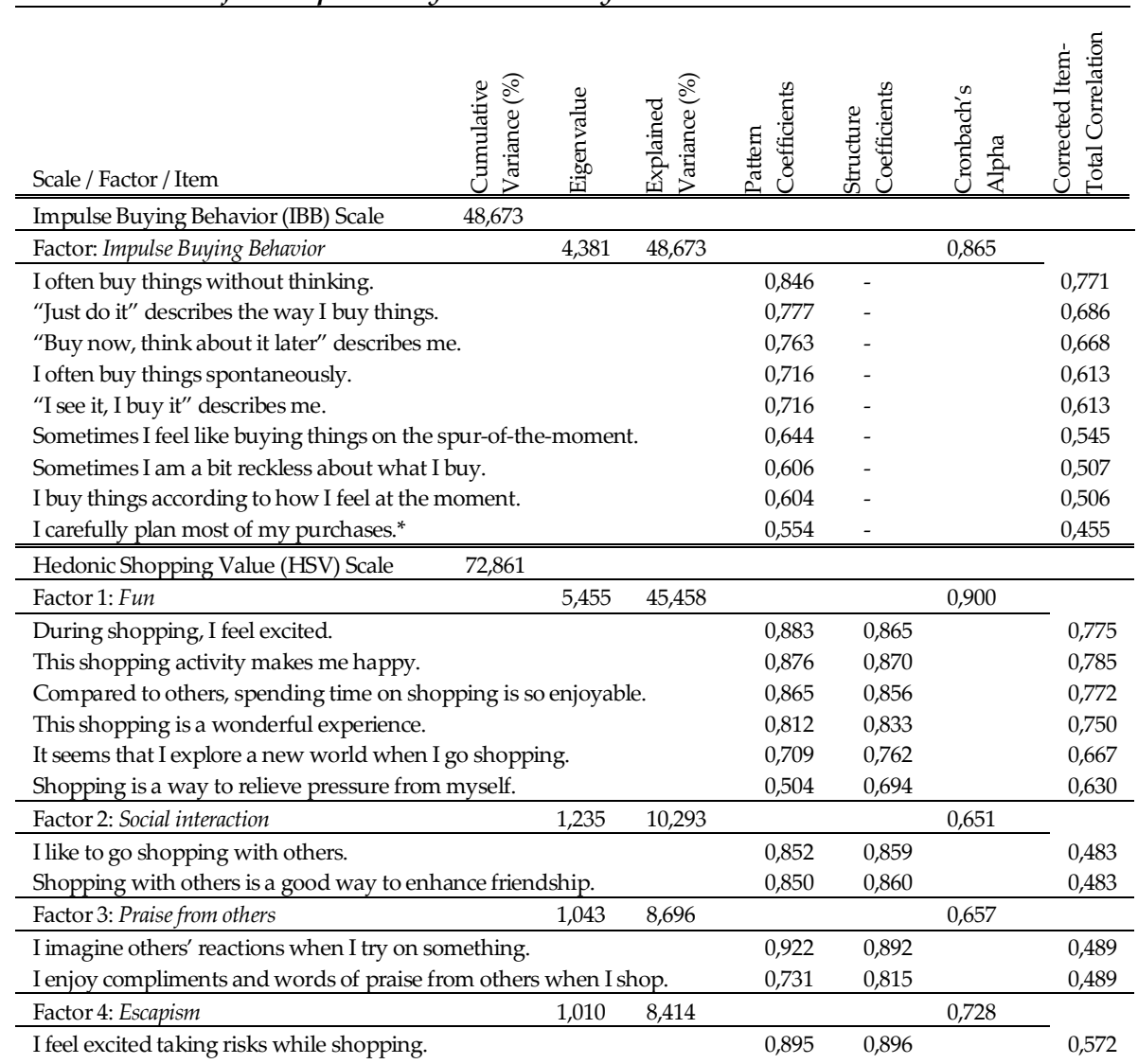




\begin{tabular}{|c|c|c|c|c|c|}
\hline \multicolumn{2}{|l|}{ I can escape from reality. } & 0,723 & 0,821 & & 0,572 \\
\hline Materialism Scale & & & & & \\
\hline Factor 1: Success & 30,760 & & & 0,689 & \\
\hline \multirow{2}{*}{\multicolumn{2}{|c|}{$\begin{array}{l}\text { I like a lot of luxury in my life. } \\
\text { Some of the most important achievements in life include acquiring mate- } \\
\text { rial possessions. }\end{array}$}} & 0,722 & 0,745 & & 0,524 \\
\hline & & 0,713 & 0,692 & & 0,421 \\
\hline \multicolumn{2}{|c|}{ I like to own things that impress people. } & 0,702 & 0,704 & & 0,461 \\
\hline \multicolumn{2}{|l|}{ I admire people who own expensive homes, cars, and clothes. } & 0,690 & 0,710 & & 0,485 \\
\hline Factor 2: Centrality 1,265 & 14,060 & & & 0,617 & \\
\hline \multirow{2}{*}{\multicolumn{2}{|c|}{$\begin{array}{l}\text { I usually buy only the things I need.* } \\
\text { I try to keep my life simple, as far as possessions are concerned.* }\end{array}$}} & 0,883 & 0,875 & & 0,447 \\
\hline & & 0,729 & 0,774 & & 0,447 \\
\hline Factor 3: Happiness 1,235 & 13,720 & & & 0,558 & \\
\hline \multicolumn{2}{|l|}{ I have all the things I really need to enjoy life.* } & 0,793 & 0,778 & & 0,391 \\
\hline \multicolumn{2}{|l|}{ I wouldn't be any happier if I owned nicer things.* } & 0,763 & 0,751 & & 0,364 \\
\hline \multicolumn{2}{|l|}{ My life would be better if I owned certain things I don't have. } & 0,564 & 0,632 & & 0,349 \\
\hline
\end{tabular}

* Reverse code

It can be observed when Table 3 is examined that the expressions in the IBB scale have been collected under a single factor following the factor analysis and that it explains about $48,673 \%$ of the total variance. It is accepted that the explained variance is at least $30 \%$ for a single factor structure (Büyüköztürk, 2006). It is observed that the expressions in the HSV scale are collected under four factors with an exploratoriness of $72,861 \%$ and that the expressions in the materialism scale are collected under three factors which explain $58,540 \%$ of the total variance. It is reasonable that the explained total variance ratio is at least $50 \%$ for structures with multiple factors (Habing, 2005).

Cronbach's Alpha coefficient was used for the reliability analysis carried out to determine internal consistency. The scale has low reliability if the Cronbach's Alpha value is above 0,40 and below 0,60 and it is reliable if the value is above 0,60 and below 0,80 . The scale has high reliability if the Alpha value is above 0,80 and below 1 (Karagöz, 2016; Kayış, 2008). Accordingly, it can be seen when the Cronbach's Alpha coefficients presented in Table 3 are examined that the Cronbach's Alpha coefficient values are between 0,9 and 0,617, which only the Cronbach's Alpha coefficient is 0,558 for the happiness factor of the materialism scale.

Reliability is related with the sample group (Pallant, 2017). It has been indicated that different reliability values can be obtained with the same scale using more homogeneous or heterogeneous sample groups (Thompson, 2003). Since the sample group of the present study was comprised of students at a university in Turkey, it can be indicated to have an effect on the 
Cronbach's Alpha coefficient that the sample group is different with regard to the homogeneity/heterogeneity of the sample group used in the reference scales. In addition, Altunışık, Coşkun, Bayraktaroğlu and Yıldırım (2005) state that Cronbach's Alpha coefficient of up to 0,5 is accepted by various researchers as acceptable for analysis studies. Furthermore, George and Mallery (2003) state that the unacceptable Cronbach's Alpha coefficient is below 0,5. Pallant (2017) indicate that the Cronbach's Alpha coefficient related with the number of items of the scale and which is used for measuring internal consistency can be low (e.g.: 0,5) for short scales and that it would be better to calculate the inter-item correlation average when low Cronbach's Alpha value is obtained. Accordingly, the corrected item-total correlation values were evaluated with Cronbach's Alpha coefficient and the values are presented in Table 3.

In general items with item-total correlation values of 0,30 and above distinguish the individuals well (Büyüköztürk, 2006). As can be seen in Table 3, internal consistency is at a sufficient and satisfactory level since the corrected item-total correlations values used in the reliability analysis are greater than 0,30 (between 0,349 and 0,785 ).

It was observed in the study as a result of the factor structures put forth via explanatory factor analysis that the test measurements generally support the theoretical structure. The expressions in the materialism scale are collected under 3 factors and are in accordance with the study by Richins and Dawson (1992). It was observed that the expressions in the impulse buying scale are collected under a single factor. This indicates the accordance of the factor structure determined as a result of the factor analysis with that of the study by Rook and Fisher (1995). HSV was taken into consideration in the study by Yu and Bastin (2010) as 5 dimensional (fun, social interaction, praise from others, escapism and novelty). As a result of the factor analysis applied in this study, it was found that the expressions in the HSV were collected under 4 factors. The factors determined in the scales as a result of factor analysis were named by taking into consideration the expressions collected under the factors and using the expressions in the factor names on the original scales that were taken as reference. The single factor in the impulse buying scale was named as "IBB" and the factors in the materialism scale were named as "success", "centrality" and "happiness" respectively. The factors in the HSV scale 
were named as, "fun", "social interaction", "praise from others" and "escapism".

Following the explanatory factor analysis, confirmatory factor analysis was applied in the study for the measurement model and the findings in Table 4 have been determined after the required modifications.

Table 4. Fit Indices for the Research Model

\begin{tabular}{llll}
\hline Model Fit Indices & Results & Suggested Value & References \\
\hline$\chi^{2} / \mathrm{df}$ & 2,070 & $\leq 3$ & Hayduck $(1987)$ \\
\hline CFI & 0,926 & $\geq 0,9$ & Bagozzi and Yi (1988) \\
\hline TLI & 0,914 & $\geq 0,9$ & Bentler and Bonett $(1980)$ \\
\hline IFI & 0,927 & $\geq 0,9$ & Bentler and Bonett $(1980)$ \\
\hline RMSEA & 0,049 & $\leq 0,08$ & Jarvenpaa et al. $(2000)$ \\
\hline
\end{tabular}

The findings in Table 4 presenting the fit indices for the model indicate that the model fits the acquired data at a satisfactory level. As can be seen in the table, the fit values of the model are statistically proved to be significant and valid.

The research hypotheses were tested by SEM using Amos. The structural model of the research is presented in Figure 2. The results of the performed hypothesis tests are summarized in Table 5 .

As can be seen in Table 5, findings indicate that the effects of the success dimension of materialism on all dimensions of HSV are statistically significant. Hence, H1 ( $\beta=1.674 ; \mathrm{p}<0,05), \mathrm{H} 2(\beta=1.172 ; \mathrm{p}<0,05), \mathrm{H} 3(\beta=1.259 ; \mathrm{p}<0,05)$ and $\mathrm{H} 4(\beta=0.947 ; \mathrm{p}<0,05)$ are supported. It was observed that the effects of the centrality dimension of materialism on HSV dimensions are not statistically significant. Thus, H5 ( $\beta=0.215 ; \mathrm{p}>0,05), \mathrm{H} 6(\beta=0.067 ; \mathrm{p}>0,05), \mathrm{H} 7$ $(\beta=0.016 ; p>0,05)$ and $\mathrm{H} 8(\beta=0.064 ; p>0,05)$ are not supported. It was assumed that the happiness dimension of materialism has a statistically significant effect on fun (H9), praise from others (H10), escapism (H11) and social interaction (H12). The findings indicate that the effects of the happiness dimension are statistically significant. Hence, H9 $(\beta=-1.898 ; \mathrm{p}<0,05), \mathrm{H} 10(\beta=-1.130 ; \mathrm{p}<$ $0,05), \mathrm{H} 11(\beta=-1.255 ; \mathrm{p}<0,05)$ and H12 $(\beta=-1.269 ; \mathrm{p}>0,05)$ are supported. 


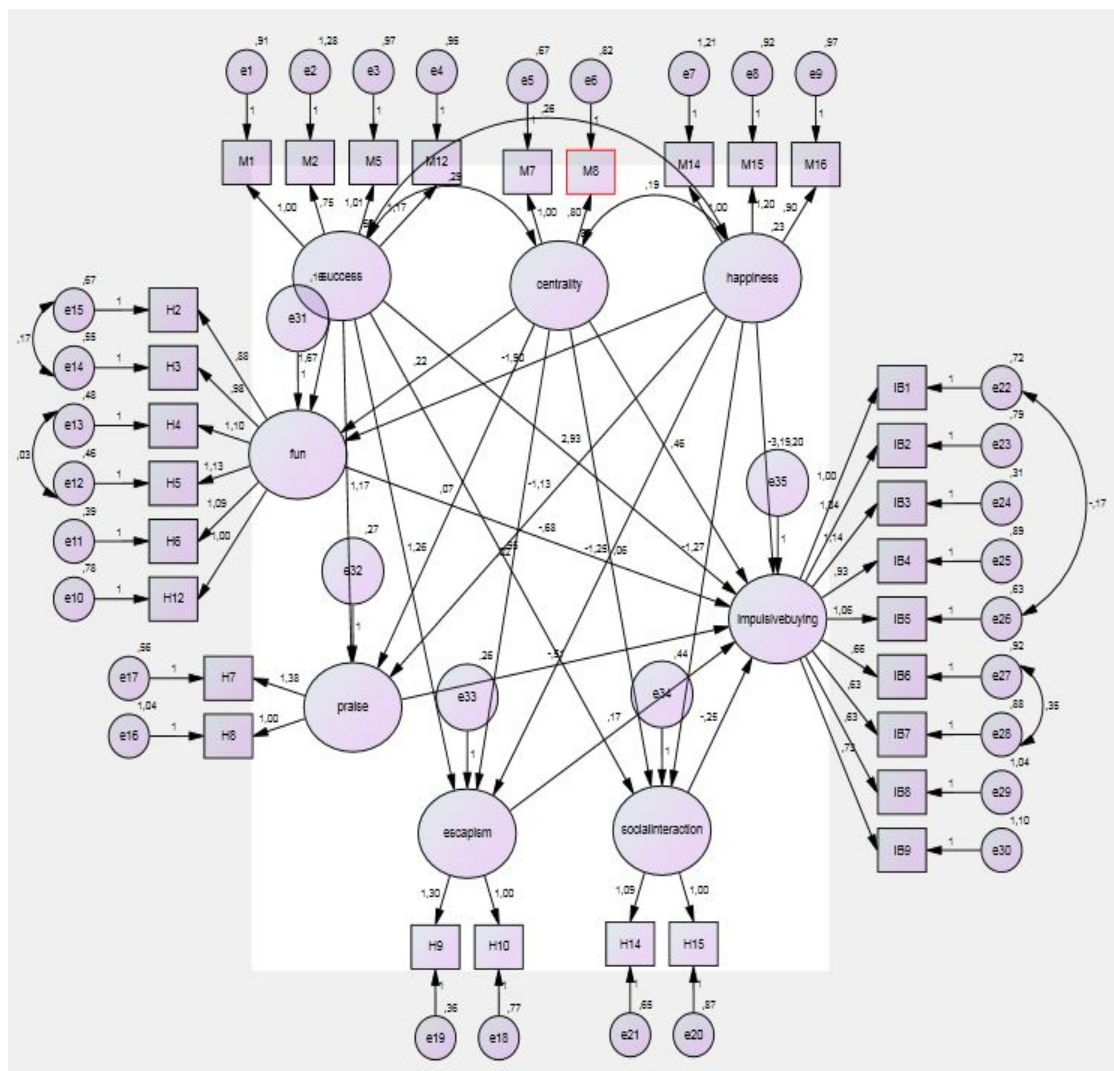

Figure 2. Structural Model

It was assumed that materialism and HSV have statistically significant effects on IBB. The findings put forth that all dimensions of materialism and the social interaction and praise from others dimensions of HSV have statistically significant effects on IBB and that the fun and escapism dimensions of the HSV do not have statistically significant effects. Therefore, H14 ( $\beta=-0,513 ; p$ $<0,05)$, H16 $(\beta=-0,252 ; \mathrm{p}<0,05), \mathrm{H} 17(\beta=2,930 ; \mathrm{p}<0,05), \mathrm{H} 18(\beta=0,463 ; \mathrm{p}<0,05)$ and H19 $(\beta=-3,194 ; p<0,05)$ are supported, while H13 $(\beta=-0,675 ; p>0,05)$ and $\mathrm{H} 15(\beta=0,174 ; \mathrm{p}>0,05)$ are not supported. 
Table 5. Structural Equation Model Findings

\begin{tabular}{|c|c|c|c|c|}
\hline Hypothesis & Relationship & Estimate & CR & Sig. \\
\hline H1 & Success $\rightarrow$ Fun & 1,674 & 7,564 & $0,000^{* * *}$ \\
\hline $\mathrm{H} 2$ & Success $\rightarrow$ Praise from others & 1,172 & 6,547 & $0,000^{* * *}$ \\
\hline H3 & Success $\rightarrow$ Escapism & 1,259 & 7,101 & $0,000^{* * *}$ \\
\hline H4 & Success $\rightarrow$ Social interaction & 0,947 & 5,387 & $0,000^{* * *}$ \\
\hline $\mathrm{H} 5$ & Centrality $\rightarrow$ Fun & 0,215 & 1,871 & 0,061 \\
\hline $\mathrm{H} 6$ & Centrality $\rightarrow$ Praise from others & 0,067 & 0,771 & 0,441 \\
\hline $\mathrm{H} 7$ & Centrality $\rightarrow$ Escapism & 0,016 & 0,175 & 0,861 \\
\hline $\mathrm{H} 8$ & Centrality $\rightarrow$ Social interaction & 0,064 & 0,670 & 0,503 \\
\hline H9 & Happiness $\rightarrow$ Fun & $-1,898$ & $-4,930$ & $0,000^{* * *}$ \\
\hline H10 & Happiness $\rightarrow$ Praise from others & $-1,130$ & $-4,211$ & $0,000^{* * *}$ \\
\hline H11 & Happiness $\rightarrow$ Escapism & $-1,255$ & $-4,512$ & $0,000^{* * *}$ \\
\hline H12 & Happiness $\rightarrow$ Social interaction & $-1,269$ & $-4,237$ & $0,000^{* * *}$ \\
\hline $\mathrm{H} 13$ & Fun $\rightarrow \mathrm{IBB}$ & $-0,675$ & $-1,570$ & 0,116 \\
\hline H14 & Praise from others $\rightarrow$ IBB & $-0,513$ & $-2,942$ & $0,003^{* *}$ \\
\hline H15 & Escapism $\rightarrow$ IBB & 0,174 & 1,062 & 0,288 \\
\hline H16 & Social interaction $\rightarrow$ IBB & $-0,252$ & $-2,289$ & $0,022^{*}$ \\
\hline H17 & Success $\rightarrow$ IBB & 2,930 & 2,302 & $0,021^{*}$ \\
\hline H18 & Centrality $\rightarrow$ IBB & 0,463 & 1,974 & $0,048^{*}$ \\
\hline H19 & Happiness $\rightarrow$ IBB & $-3,194$ & $-2,004$ & $0,045^{*}$ \\
\hline
\end{tabular}

\section{Discussion and Conclusion}

This study investigated the effects of materialism and HSV on IBB and the effect of materialism on HSV. The data acquired from students at one state university in Turkey were analyzed by factor analysis and SEM. As a conclusion, it was observed that the success dimension, which is one of the three dimensions expressing materialism, has a significant and positive effect on all dimensions of HSV. Accordingly, individuals who define success as the amount and value of owned tangible goods, who enjoy owning things that impress people, who like luxurious life and who admire those who own expensive things are of the opinion that they can impress people and strengthen their images by buying valuable products and hence prove that they are successful individuals, it is possible to state that during shopping these individuals also meet their hedonistic demands such as social interaction, praise from others, escapism and fun, because it was determined that the success dimension has a significant and positive effect on the fun, social interaction, praise from others and escapism dimensions of HSV. This result of the study indicating that materialism has an effect on HSV is in accordance with the findings of studies by Burroughs and Rindfleisch (2002); Lins et al. (2015) and 
Seo and Huh (2004). It was observed in the study that the centrality dimension of materialism does not have a statistically significant effect on HSV. Moreover, it was determined that the happiness dimension of materialism has a negative and significant effect on fun, social interaction, praise from others and escapism dimensions of the HSV. This result of the study can be explained in line with the fact that Babin et al. (1994) characterized the HSV as a therapeutic activity, and Thompson, Locander and Pollio (1990) described consumers who, in a case study, went shopping for something fun when they felt depressed. This result can be interpreted such that a happy young individual who is content with what he/she owns and who enjoys life does not need fun, social interaction, praise from others and escapism via HSV to be especially happy.

It was observed that the success and centrality dimensions of materialism have a significant and positive effect on IBB. This result of the study is in accordance with the findings of Lins et al. (2015) and Troisi et al. (2006). It can be put forth that this result supports the idea that materialism plays a considerable role in motivating IBB for young consumers who have a tendency for buying due to the gaps between their actual and ideal selves or for strengthening their images and expressing their selves by way of the material things they own. Hence, it can be stated that it impulse buying under stimulation is inevitable for individuals who identify success with the value and amount of the goods and property they have, who place owning tangible goods at the center of their lives and who see it as a fundamental goal of life. On the other hand, it was also concluded that the happiness dimension of materialism has a significant and negative effect on IBB. This result of the study is in accordance with the research finding of Silvera, Lavack and Kropp (2008) that impulse buying is negatively associated to subjective well-being, and the research finding of Verplanken, Herabadi, Perry and Silvera (2005) that impulse buying is driving by low self-esteem and negative mood state effects. Because happiness is called subjective well-being in the literature (Diener, 2000; Scorsolini-Comin and dos Santos, 2010) and is used interchangeably (Diener, 1994; Proctor, 2014). It can be indicated that this result is due to the fact that the study has been carried out on a population comprised of university students. It is possible to indicate that the impulse buying probabilities especially with the aim of being happy will be low for university students who are of the opinion that they have almost everything to enjoy life. It can be suggested 
that the two results indicating the happiness dimension has a negative effect on both HSV and IBB, support each other. Li, Patel, Balliet, Tov, and Scollon (2011) determined in their study in two different countries that materialismbased happiness has different effects in different countries.

Another result of this study indicates that the social interaction and praise from others dimensions of HSV have a significant and negative effect on IBB. This result is by contrast with the results of studies by Babin et al. (1994); Herabadi et al. (2009); Lins et al. (2015); Mamuaya and Tumiwa (2017) and Miao (2011). However, this result of the study is in accordance with the research finding of Rook and Fisher (1995) that impulsive trait tendencies are moderated by normative effects and negative normative evaluations can discourage consumers from impulse buying. Because individuals who want to be accepted, liked and appreciated by their social environment will behave accordingly. Also, Yu and Bastin (2010) put forth an insignificant negative relationship between the social interaction dimension and impulse buying intention while Cinjarevic, Tatic and Petric (2011) between social shopping and IBB. The statistically significant result of this study which puts forth that the social interaction dimension has a negative effect on impulse buying can be explained as the fact that individuals who especially like shopping with others and who consider shopping together as an effective means for improving friendship, they refrain from IBB. Because IBB do not enable the opportunity of taking consideration of the other people's opinions. Moreover, it can also be stated that these consumers try to show to those around them that they are balanced and reasonable individuals by refrain from impulse buying and that their behaviors are consistent. Yu and Bastin (2010) put forth within the context of social interaction that people tend to strive to control their IBB in order to avoid being perceived as immature individuals who act unreasonably. The fact that the praise from others dimension was shown to have a negative and significant effect on IBB supports the negative relation between social interaction and impulse buying and strengthens its meaning. It can be stated that consumers who enjoy being approved by others when they try a new product and who want to receive praise when they shop shall refrain from IBB with motives of receiving praise and compliments and that they will opt for planned shopping in accordance with the expectations of the society.

When these two dimensions (social interaction and praise from others) which are reported to have a negative effect on IBB are evaluated together, it 
can be inferred that consumers who wish to receive praise from others and who want to show to their social environment that they are acting consistently shall be uncomfortable and unhappy in cases of impulse buying and that they will feel emotions which will make them sad. As another finding of the study indicating that the fun dimension of HSV has a negative effect on IBB at a statistically insignificant level can be considered to be related with this. Because it can be assumed that individuals who are restless and unhappy in cases of impulse buying shall refrain from IBB since they will not have fun when they shop on impulse. With regard to this evaluation, the aforementioned result is also in accordance with the results of the study by Rook (1987) indicating that intensive emotions accompany IBB that the emotions accompanying impulse buying contain hedonic elements for about half of the participants and that IBB is accompanied by emotions that make the individual feel bad for some individuals. However, further studies on this topic are required in order to verify this assumption. It was also observed in the study that the escapism dimension of HSV has a positive effect on IBB but not at a statistically significant level. Yu and Bastin (2010) also mentioned in their studies a positive and statistically insignificant relationship between escapism and impulse buying intention. This result is also in accordance with the study by Yu and Bastin (2010).

These results which put forth the effect of materialism on HSV and IBB as well as the effects of HSV on IBB, also point out that in general the young individuals included in the study in Turkey consider themselves happy. Also, it shows that they give importance to social interaction and pay attention to acting in a balanced and consistent manner in accordance with the expectations of the society and their environment.

Based on the study results, it can be suggested to businesses to develop various strategies for increasing the value perceived by the customer by emphasizing the pleasure/hedonism provided by the products as well as ownership and acquisitions/materialism. With regard to businesses, it will be profitable to target highly materialistic individuals. In addition, individuals with low levels of materialism and hedonism should also be taken into consideration separately by marketers using different means of persuasion. The study is also important for acquiring information on the financial status of 
young individuals and their impulses for shopping. Knowledge of the shopping habits of young people may enable them to establish healthier relationships with money in general.

The study has various limitations. The data were acquired in the study via convenience sampling method only from a sample group comprised of students at one university in Turkey. Since the study was carried out with a sample group representing university students in Turkey, the results cannot be generalized. University students are relatively homogeneous (Thomas, Esper and Stank, 2010). Therefore, the demographic and personal factors that may have a moderating impact on the relationships between the research variables were left outside the scope of this study since the sample group of this study is relatively more homogeneous than a normal population. It may be beneficial to evaluate how the relationships between the research variables vary with regard to demographic and personal factors by using a more general consumer population in future studies. It may also be suggested for future studies to carry out studies comparing different countries. Also, carrying out an experimental study for evaluating the research variables will also make significant contributions to literature.

\section{References}

Akalın, Ş. H., Toparlı, R., Argunşah, M., Demir, N., Gözaydın, N., Özyetgin, A. M., ...Tekeli, S. (2011). Türkçe Sözlïk [Turkish Dictionary] (11th ed.), Ankara, Turkey: Türk Dil Kurumu.

Altunışık, R., Coşkun, R., Bayraktaroğlu, S., and Yıldırım, E. (2005). Sosyal bilimlerde araştırma yöntemleri: SPSS uygulamalı [Research methods in social sciences: SPSS applied] (4th ed.). Sakarya, Turkey: Sakarya Kitabevi.

Amos, C., Holmes, G.R., and Keneson, W.C. (2014). A meta-analysis of consumer impulsive buying. Journal of Retailing and Consumer Services, 21 (2), 86-97.

Arnold, M. J., and Reynolds, K. E. (2003). Hedonic shopping motivations. Journal of Retailing, 79(2), 77-95.

Aytekin, P., and Ay, C. (2015). Hedonik tüketim ve anllk satın alma ilişkisi [Relationship between hedonic consumption and impulse buying]. Niğde Üniversitesi İktisadi ve İdari Bilimler Fakültesi Dergisi, 8(1), 141-156.

Babin, B. J., Darden, W. R., and Griffin, M. (1994). Work and/or fun: Measuring hedonic and utilitarian shopping value. Journal of Consumer Research, 20(4), 644-656. 
Badgaiyan, J. A., and Verma, A. (2014). Intrinsic factors affecting impulsive buying behaviour - Evidence from India. Journal of Retailing and Consumer Services, 21, 537-549.

Badgaiyan, J. A., and Verma, A. (2015). Does urge to buy impulsively differ from impulse buying behavior? Assessing the impact of situational factors, Journal of Retailing and Consumer Services, 22, 145-155.

Bagozzi, R., and Yi, Y. (1988). On the evaluation of structural equation models. Journal of the Academy of Marketing Sciences, 16(1), 74-94.

Beatty, S. E., and Ferrell, M. E. (1998). Impulse buying: Modeling its precursors. Journal of Retailing, 74(2), 169-191.

Belk, W. R. (1984). Three scales to measure constructs related to materialism: Reliability, validity and relationships to measures of happiness. In T. C. Kinnear (Ed.) Advances in Consumer Research 11, (p. 291-297). Provo, UT: Association for Consumer Research. Retrieved 02 February 2019, from https://acrwebsite.org/volumes/6260/volumes/v11/NA-11

Bellenger, D.N., Robertson, D.H., and Hirschman E.C. (1978). Impulse buying varies by product. Journal of Advertising Research, 18 (6), 15-18. Retrieved 01 March 2019, from $\quad$ http://eds.b.ebscohost.com/eds/pdfviewer/pdfviewer?vid=2andsid=9ffe02ae-3580-4f6a-936d-0dd0bc8d8cb6\%40pdc-v-sessmgr02

Bentler, P. M., and Bonett, D. G. (1980). Significance tests and goodness of fit in the analysis of covariance structures. Psychological Bulletin, 88(3), 588-606.

Burroughs, J. E., and Rindfleisch, A. (2002). Materialism and well-being: A conflicting values perspective. Journal of Consumer Research, 29(3), 348-370.

Büyüköztürk, Ş. (2006). Veri Analizi El Kitabı [Handbook of Data Analysis] (6th ed.), Ankara, Turkey: Pegem A.

Cinjarevic, M., Tatic, K., and Petric, S. (2011). See it, like it, buy it! Hedonic shopping motivations and impulse buying. Economic Review: Journal of Economics and Business, 9(1), 3-15.

Cobb, C. J., and Hoyer, W. D. (1986). Planned versus impulse purchase behaviour. Journal of Retailing, 62(4), 384-409.

Coley, A., and Burgess, B. (2003). Gender differences in cognitive and affective impulse buying. Journal of Fashion Marketing and Management: An International Journal, 7(3), 282-295.

Çağlıyan, V., Gültekin, C., and Gelmez, E. (2018). A study on hedonic consumption and impulse buying behavior on university students. In III. Ines Education and Social Science Congress Full Text Book (pp. 1537-1544), Alanya/Antalya, Turkey. 
Diener, E. (1994). Assessing subjective well-being: Progress and opportunities. Social Indicators Research, 31(2), 103-157.

Diener, E. (2000). Subjective well-being: The science of happiness and a proposal for a national index. American Psychologist, 55(1), 34-43.

Dittmar, H., Beattie, J., and Friese, S. (1995). Gender identity and material symbols: Objects and decision considerations in impulse purchases. Journal of Economic Psychology, 16(3), 491-511.

Ducoffe, R. H. (1996). Advertising value and advertising on the web. Journal of Advertising Research, 36(5), 21-35.

Fitzmaurice, J., and Comegys, C. (2006). Materialism and social consumption. Journal of Marketing Theory and Practice, 14(4), 287-299.

Garðarsdóttir, R. B., and Dittmar, H. (2012). The relationship of materialism to debt and financial well-being: The case of Iceland's perceived prosperity. Journal of Economic Psychology, 33(3), 471-481.

Ghani, U., and Jan, F.A. (2011). An exploratory study of the impulse buying behaviour of urban consumers in Peshawar. 2010 International Conference on Business and Economics Research, Vol. 1, Kuala Lumpur, Malaysia: IACSIT Press, Retrieved 01 March 2019, from https://pdfs.semanticscholar.org/alea/ dffa5a8798cdc1d850dba50ce382ec096864.pdf

George, D., and Mallery, P. (2003). SPSS for Windows step by step: A simple guide and reference 11.0 update. (4th ed.). Boston, MA: Allyn and Bacon.

Habing, B. (2005). Exploratory factor analysis. Working Paper. University of South Carolina, Columbia, SC. Retrieved 12 June 2019, from http://people.stat.sc.edu/habing/courses/530/EFA2005.pdf

Hair Jr., J. F., Black, W. C., Babin, B. J. and Anderson R. E. (2014). Multivariate data analysis. (7th ed.). Harlow/Essex, UK: Pearson Education. Retrieved 22 June 2019, from https://is.muni.cz/el/1423/podzim2017/PSY028/um/ Hair - Multivariate data analysis 7 th revised.pdf

Hayduk, L. A. (1987). Structural equation modeling with LISREL: Essentials and advances. Baltimore, MD: The Johns Hopkins University Press.

Herabadi, A. G., Verplanken, B., and Knippenberg A. V. (2009). Consumption experience of impulse buying in Indonesia: Emotional arousal and hedonistic considerations. Asian Journal of Social Psychology, 12(1), 20-31.

Hirschman, E. C. (1983). Predictors of self-projection, fantasy fulfillment and escapism. The Journal of Social Psychology, 120(1), 63-76. 
Impulse Purchase (n.d.). In Marketing Accountability Standards Board's online common language marketing dictionary. Retrieved 10 August 2020, https://marketing-dictionary.org/i/impulse-purchase/

Jarvenpaa, S. L., Tractinsky, N., and Vitale, M. (2000). Consumer trust in an internet store. Information Technology and Management, 1(1-2), 45-71.

Kacen, J. J. (2003). Bricks and amp; clicks and amp; the buying impulse: An investigation of consumer impulse buying behavior in an online and a traditional retail environment. In D. Turley and S. Brown (Eds.), European Advances in Consumer Research 6, (p. 271-276). Provo, UT: Association for Consumer Research. Retrieved 06 February 2019, from http://acrwebsite.org/volumes/11248/volumes/e06/E-06

Kacen, J. J., and Lee, J. A. (2002). The influence of culture on consumer impulsive buying behaviour. Journal of Consumer Psychology, 12(2), 163-176.

Karagöz, Y. (2016). SPSS 23 ve AMOS 23 uygulamal istatistik analizler [SPSS 23 and AMOS 23 applied statistical analysis]. Ankara, Turkey: Nobel Akademik.

Kayış, A. (2008). Güvenilirlik analizi [Reliability analysis]. In Ş. Kalaycı (Ed.). SPSS uygulamalı çok değişkenli istatistik teknikleri [SPSS applied multivariate statistical techniques] (p. 403-419). Ankara, Turkey: Asil.

Kollat, D. T., and Willett, R. P. (1969). Is impulse purchasing really a useful concept for marketing decisions? The Journal of Marketing, 33(1), 79-83.

Li, N. P., Patel, L., Balliet, D., Tov, W., and Scollon, C. N. (2011). The incompatibility of materialism and the desire for children: Psychological insights into the fertility discrepancy among modern countries. Social Indicators Research, 101, 391-404.

Lins, S., Bottequin, E., Dóka, A., Golasa A., Hylander, F., Merchán, A., ... Pavlović, S. (2013). To think, to feel, to have: The effects of need for cognition, hedonism and materialism on impulse buying tendencies in adolescents. Journal of European Psychology Students, First Work in Progress Special Edition, 25-32.

Lins, S., Dóka, Á., Bottequin, E., Odabašić, A., Pavlović, S., Merchán, A., ... Hylander, F. (2015). The Effects of Having, Feeling, and Thinking on Impulse Buying in European Adolescents. Journal of International Consumer Marketing, 27(5), 414-428.

Mamuaya, N. C., and Tumiwa, A. F. (2017). The effect of situational factor on hedonic shopping motivation and impulsive buying of college students in mall at Manado City. International Journal of Business and Management Invention (IJBMI), 6 (12), 44-50.

Miao, L. (2011). Guilty pleasure or pleasurable guilt? Affective experience of impulse buying in hedonic driven consumption. Journal of Hospitality and Tourism Research, 35(1), 79-101. 
O'Brien, S. (2018, February 23). Consumers cough up $\$ 5,400$ a year on impulse purchases. CNBC. Retrieved 10 February 2019, from https://www.cnbc.com/2018/02/23/consumers-cough-up-5400-a-year-on-impulse-purchases.html

Pallant, J. (2017). SPSS kullanma klavuzu: SPSS ile admm admm veri analizi [SPSS survival manuel: A step by step guide to data analysis using IBM SPSS] (Trans. S. Bala and B. Ahi, 2nd ed.). Ankara, Turkey: Anu (Original work published 2015).

Point of Purchase Advertising International (2014). Mass merchant shopper engagement study. Retrieved 04 February 2019, from http://memberconnect.shopassociation.org/HigherLogic/System/DownloadDocumentFile.ashx?DocumentFileKey=af210ce1-cdb1-d6fb-7306-8970cb321e60

Proctor, C.L., (2014). 'Subjective well-being', in A.C. Michalos (ed.), Encyclopedia of quality of life and well-being research, p. 6437-6441, Amsterdam: Springer.

Richins, M. L. (1987). Media, materialism, and human happiness. In M. Wallendorf and P. Anderson (Eds.), Advances in Consumer Research 14, (p. 352-356). Provo, UT: Association for Consumer Research. Retrieved 12 February 2019, from http://acrwebsite.org/volumes/6720/volumes/v14/NA-14

Richins, M. L., and Dawson, S. (1992). A consumer values orientation for materialism and its measurement: Scale development and validation. Journal of Consumer Research, 19(3), 303-316.

Rook, D.W. (1987). The buying impulsive. Journal of Consumer Research, 14(2), 189-199.

Rook, D. W., and Fisher, R. J. (1995). Normative influences on impulsive buying behavior. Journal of Consumer Research, 22(3), 305-313.

Rook, D. W., and Hoch, S. J. (1985). Consuming impulses. In E. C. Hirschman and M. B. Holbrook (Eds.), Advances in Consumer Research 12, (p. 23-27). Provo, UT: Association for Consumer Research. Retrieved 09 February 2019, from http://acrwebsite.org/volumes/6351/volumes/v12/NA-12

Rudawska, E., Petljak, K., and Stulec, I. (2015). Hedonic or utilitarian buying behaviours - what values do young adult customers seek in online group buying? International Journal Business Performance Management, 16(2/3), 182-197.

Scorsolini-Comin, F., and dos Santos, M. A. (2010). The scientific study of happiness and health promotion: an integrative literature review. Revista Latino-Americana de Enfermagem, 18(3), 472-479.

Sekeran, U. (1992). Research methods for business: A skill building approach. (2nd ed.). New York, NY: John Wiley and Sons.

Sen, S., and Nayak, S. (2019). Influence of materialism on impulsebuying among Indian millennials: Does Income Matter? Indian Journal of Marketing, 49(12), 47-60. 
Seo, J.-H., and Huh, E.-J. (2004). Cross cultural comparison of materialism and hedonic and utilitarian shopping value: Using Korean, American and Japanese college students. Korean Journal of Human Ecology, 13(5), 765-776. Retrieved 12 February 2019, from http://www.koreascience.or.kr/article/ IAKO200429217126252.page

Silvera, D. H., Lavack, A. M., and Kropp, F. (2008). Impulse buying: The role of affect, social influence, and subjective wellbeing. Journal of Consumer Marketing, 25(1), 23-33.

Stern, H. (1962). The significance of impulsebuying today. Journal of Marketing, 26(2), 59-62.

Tauber, E. M. (1972). Marketing notes and communications: Why do people shop? Journal of Marketing, 36(4), 46-49.

Thomas, M., Desai, K. K., and Seenivasan, S. (2011). How credit card payments increases unhealthy food purchases: visceral regulation of vices. Journal of Consumer Research, 38(1), 126-139.

Thomas, R.W., Esper, T. L., and Stank, T. P. (2010). Testing the negative effects of time pressure in retail supply chain relationships. Journal of Retailing, 86(4), 368-382.

Thompson, B. (2003). Guidelines for authors reporting score reliability estimates. In B. Thompson (Ed.). Score reliability: Contemporary thinking on reliability issues (pp. 91-102). Thousand Oaks, CA: Sage. Retrieved 22 June 2019, from https://books.google.co.tz/books?id=gv10AwAAQBAJandpg=PA91\&hl=tr\&source $=$ gbs toc $r \& c a d=2 \# v=$ onepage\& $q \& f=$ false

Thompson, C. J., Locander, W. B., and Pollio, H. R. (1990). The Lived Meaning of Free Choice: An Existential-Phenomenological Description of Everyday Consumer Experiences of Contemporary Married Women. Journal of Consumer Research, 17(3), 346-361.

Tifferet, S., and Herstein, R. (2012). Gender differences in brand commitment, impulse buying, and hedonic consumption. Journal of Product \& Brand Management, 21(3), 176-182.

Troisi, J. D., Christopher, A. N., and Marek P. (2006). Materialism and money spending disposition as predictors of economic and personality variables. North American Journal of Psychology, 8(3), 421-436.

TUIK Turkish Statistical Institute (2019). Youth in Statistics - Period: 2018. Social Structure and Gender Statistic. Press Releases. Retrieved 02 March 2020, from http://www.turkstat.gov.tr/PreTablo.do? alt id=1068

Verplanken, B., Herabadi, A. G., Perry, J. A., and Silvera, D. H. (2005). Consumer style and health: The role of impulsive buying in unhealthy eating. Psychology $\mathcal{E}$ Health, 20(4), 429-441. 
Ward, S., and Wackman, D. (1971). Family and media influences on adolescent learning. American Behavioral Scientist, 14(3), 415-427.

Watson, J. (2003). The relationship of materialism to spending tendencies, saving and debt. Journal of Economic Psychology, 24(6), 723-739.

Wu, I-L., Chiu, M-L., and Chen, K-W. (2020). Defining the determinants of online impulse buying through a shopping process of integrating perceived risk, expectation-confirmation model, and flow theory issues. International Journal of Information Management, 52, Retrieved 02 March 2020, from https://www.sciencedirect.com/science/article/pii/S0268401219306759

Yalova University (2019). 2018 Yilı Faaliyet Raporu [Activity Report for 2018]. Retrieved 25 January 2019, http://oidb.yalova.edu.tr/tr/Page/Icerik/2018-yili-faaliyetraporu

Youn, S., and Faber, R.J. (2000). Impulse buying: Its relation to personality traits and cues. In Stephen J. Hoch and Robert J. Meyer (Eds.), in NA - Advances in Consumer Research 27, (pp. 179-185). Provo, UT: Association for Consumer Research. Retrieved 02 March 2020, from https://www.acrwebsite.org/volumes/8383/volumes/v27/NA-27

Yu, C., and Bastin, M. (2010). Hedonic shopping value and impulse buying behavior in transitional economies: A symbiosis in the Mainland China marketplace. Journal of Brand Management, 18(2), 105-114.

\section{Kaynakça Bilgisi / Citation Information}

Açan, B., Özhan, Ş. and Talih Akkaya, D. (2021). The effects of materialism and hedonic shopping value on the impulse buying behavior: A study on university students in Turkey. OPUS-International Journal of Society Researches, 17(36), 2518-2545. DOI: 10.26466/opus. 778848 